\title{
ANALYSIS OF THE IMPLEMENTATION OF INDUSTRY 4.0 STRATEGY IN COMPANIES IN THE STATE OF MATO GROSSO
}

\author{
Lélia Rocha Abadio Brun ${ }^{\text {a }}$, Camila de Sousa Pereira-Guizzo ${ }^{a}$ \\ a Graduate Program in Management and Industrial Technology, SENAI \\ CIMATEC University Center, Brazil
}

\begin{abstract}
In a general context, industries have had their processes and organizational models transformed by technological advances over the centuries. Named as industrial revolutions, these moments experienced by organizations have always brought the need for reinvention and transformation in organizational models. Understanding the impact of this fourth industrial revolution, known as "Industry 4.0", is necessary to enhance strategies for implementing technologies. The maturity level of industries within the scope of their strategy and organization, through the vision of the implementation of the industry 4.0 strategy is the focus of the proposed discussions, considering its current stage of maturity.
\end{abstract}

Keywords: maturity level; industry 4.0; strategy and organization.

Resumo: As empresas tiveram seus processos organizacionais transformados pelo avanço tecnológicos no decorrer dos séculos. Entender o impacto dessa quarta revolução industrial, conhecida como "Indústria 4.0", se faz necessário para potencializar estratégias de implementação das tecnologias. O objetivo deste estudo foi analisar a implementação da estratégia de indústria $4.0 \mathrm{em}$ 200 empresas do setor industrial do Estado de Mato Grosso. Os principais resultados, obtidos com a aplicação do questionário "Avaliação de Maturidade: Indústria 4.0", sugerem que as empresas do setor industrial de Mato Grosso estão buscando estratégias voltadas para a indústria 4.0 , sendo que as de médio e grande porte apresentam estruturas e organizações melhores posicionadas.

Palavras-chave: maturidade tecnológica; indústria 4.0; estratégia e organização. 


\section{INTRODUCTION}

Industry 4.0 is a term derived from the technical narratives of human evolution regarding industrialization, which in the course of great industrial transformation, became known as industrial revolutions, having their respective milestones, such as the steam engine, production line, electronics, and smart factories. Launched in 2011 though three structures of German society industry, political agents, and the national science system - the term industry 4.0 , or commonly known as the fourth industrial revolution, consolidates itself as a government strategy for advanced technology [1].

Industry 4.0, also known as the fourth industrial revolution, marks a new leap in quality in industrial production, connecting people, machines, and products, together forming a new production system, which allows a targeted and faster exchange of information. This change moves towards a future where people will collaborate with robots and be supported by web technology and intelligent assistance systems in their work activities [2-5].

However, it is not enough to address all the advances and developments associated with the fourth industrial revolution only from a technological perspective, as companies need to adapt their organization and culture. Although advanced technologies make it possible to access a much wider data range, the ability to use and leverage the potential of this data depends heavily on the organizational structure and culture of companies. Businesses should adopt learning cultures that are agile and continuous so that they can adapt to this scenario of fast and intense changes [6].

In this context of fostering industry 4.0, the importance of technological maturity arises. There are several existing methods to assess the level of technological maturity of organizations, considering the stage of implementation of industry 4.0. An example is a method of the National Academy of Science and Engineering (ACATECH), which serves as the basis for this study, having as a goal to provide means to establish the current maturity stage of companies in the context of the Industry 4.0, and identifying concrete measures to help them reach a level that can maximize the economic benefits generated by Industry 4.0 and digitalization [6].

Another example of technological Maturity level assessment methodology is a metric systematic, with nine stages, developed by the National Aeronautics and Space Administration (NASA) called Technology Maturity Level (NMT), which allows classifying new technologies, with the essential goals of enabling comparison with others, and ease understanding of the current stage of development, also, to support decisions to foster resources for innovation and those related to the transition of technology [7].

These methodologies, focused on assessing the level of technological maturity, have in common the need to demonstrate the behavior of organizations before existing technologies, and to promote an advance concerning new technologies to be implemented, to guarantee a growth sustained by knowledge of the present state of the company. Considering that understanding where the organization is inserted in this scenario favors the 
decision making to which paths the company's efforts and resources should be led, this implies the growth in a structured way to guarantee the sustainability of the adopted strategies.

The demand from the industrial sector for guidance on how to fit into the 4.0 industry theme is high. Given the need to broaden the understanding of the concepts and technologies associated with Industry 4.0, knowing and assessing the level of technological maturity of industries in the State of Mato Grosso constitutes an important contribution to the evolution of the segment in this new scenario. Thus, this study aims to analyze the implementation of industry 4.0 strategy in the dimension referring to its strategy and organization, in companies in the State of Mato Grosso [8].

\section{METHODOLOGY}

Research of a descriptive nature, which seeks to perform a quantitative analysis of the object of study. The sample of this study was composed of 200 industries in the State of Mato Grosso. These companies were selected considering their participation in the Brasil Mais Produtivo Program, an initiative of the Federal Government carried out nationwide. Of this amount, industries of all sizes (micro, small, medium, and large) were included in 29 municipalities in the state, representing 8 segments, among the wood and furniture sectors $(31.5 \%)$, food \& beverage $(30 \%)$, civil construction $(16 \%)$, clothing $(9 \%)$, nonmetallic minerals $(5.5 \%)$, plastics and rubbers $(4.5 \%)$, metal mechanics $(3 \%)$ and chemicals $(0.5 \%)$ were included.

The "Maturity Assessment: Industry 4.0" questionnaire [8], a model provided by $\mathrm{CNI}$ (National Confederation of Industries), was answered by HR managers, industrial production managers, or owners of each company. This survey and its analysis methodology were structured with support from the Instituto Tecnológico de Aeronáutica (ITA) to assess the maturity level of Brazilian industries, based on other studies [6-10]. This questionnaire consists of 34 items, which assesses 3 dimensions: Strategy and organization; Manufacturing and supply chain; Business model, products, and services. However, for this study, only the items that assess the "Strategy and Organization" dimension were used, focusing on the results related to the status of the implementation of the company's strategy regarding industry 4.0. The status of the strategy's implementation is categorized on the following scale: no defined strategy, pilot planning initiatives, strategy under development, defined strategy, strategy under implementation, and tiered strategy.

These results were analyzed quantitatively through descriptive statistics, also taking into account the size of the companies (micro, small, medium, and large). The criterion that establishes the classification of companies according to size is defined according to the number of employees and depends on the sector of economic activity investigated, considering: microbusiness up to 19 people, small business from 20 to 99, médium business from 100 to 499 and large 500 people employed or more [11]. 


\section{RESULTS AND DISCUSSION}

Among the 200 industrial companies evaluated, 74 are microbusinesses, 91 are small, 30 medium-sized, and 5 large. All of these industries were assessed for their respective strategy implementation status with a focus on industry 4.0, allowing for the categorization of answers that ranged from "no defined strategy" to "existence of a upward strategy" (Table 1).

Table 1. Results of industry responses by size regarding the status of implementation of industry 4.0 HOW DOES THE COMPANY DESCRIBE THE STATUS OF IMPLEMENTING ITS INDUSTRY 4.0 STRATEGY?

\begin{tabular}{lcccccc}
\cline { 2 - 7 } SIZE & $\begin{array}{c}\text { No } \\
\text { Strategy } \\
\text { Defined }\end{array}$ & $\begin{array}{c}\text { Pilot Planning } \\
\text { Initiatives }\end{array}$ & $\begin{array}{c}\text { Strategy in } \\
\text { Development }\end{array}$ & $\begin{array}{c}\text { Defined } \\
\text { Strategy }\end{array}$ & $\begin{array}{c}\text { Strategy in } \\
\text { implementation }\end{array}$ & $\begin{array}{c}\text { Upward } \\
\text { Strategy }\end{array}$ \\
\hline Micro & 56 & 8 & 7 & 1 & 2 & - \\
\hline Small & 61 & 11 & 14 & 3 & 2 & - \\
\hline Medium & 16 & 9 & 2 & 1 & 1 & 1 \\
\hline Large & 2 & 1 & - & - & 1 & 1 \\
\hline
\end{tabular}

The greater participation of micro, small and medium-sized industries compared to the number of large ones that initially participated in Brasil Mais Produtivo Program, a requirement for selecting the companies studied (Section 2 ), reflects the reality of the industrial ecosystem in Mato Grosso State, which according to $\mathrm{CNI}$, in general, is composed of only about $1 \%$ of large industries [9].

Although it is possible to envision a relative distribution of companies in the different scales of strategies regarding the implementation of industry 4.0, the results in Table 1 suggest the largest number of companies in the "no defined strategy" category, highlighting mainly micro and small companies in this status.

This result is sustained by the fact that the literature indicates that the micro and small companies have greater needs in relation to the understanding and establishment of strategies applied to the development of technological maturity [12]. Strategic planning of a business organization is an important tool for generating products and services competitiveness, while enabling project the prospects for growth and development in areas of technical, technological and human [13].

The contrast of absorption of the technologies of Industry 4.0 in the medium and large industries is evident, considering that there are companies of these sizes already in the maximum status of implementation "upward strategy". 
However, it is undeniable that many micro and small industrial companies in Mato Grosso are observant, whether to a greater or lesser degree, to the need for changes resulting from the fourth industrial revolution, as shown in the results in Table 1, indicating a quantitative in the statuses "developing strategies","defined strategy" and "implementation strategy".

The results presented in Table 1 indicate that medium and large-sized industries have structures and organizations better positioned and inserted in the fourth revolution. On the other hand, it should be noted that regardless of size and degree of progress, it is noted that in general the industries of the State of Mato Grosso are alert to changes and seeking to understand this scenario of industry 4.0 to guarantee the continuity and competitiveness of your business. Therefore, understanding which stage of maturity each industrial business is in is of fundamental importance for the sustainable technological development of these companies and, consequently, for the state and national economy.

Industry 4.0 has the potential to transform companies, employees and the entire chain of suppliers, partners, distributors and customers into a fully interconnected and integrated digital network, linked to other networks worldwide. This requires major changes in organizational strategies and structures, which promote the implantation and dissemination of a new digitaloriented culture [14].

\section{CONCLUSION}

It is concluded that, in general, companies in the industrial sector of Mato Grosso are looking for strategies oriented to industry 4.0. The size of the companies influenced the status of the implementation of the company's strategy oriented to industry 4.0. In medium and large industries it is already possible to find strategies in the maximum status of implementation of industry 4.0 (upward strategy). Regarding micro and small businesses, even though both usually don't present a defined strategy when the entire scale is observed, it is possible to notice an expressive number in the defined strategy and even in implementation categories, which points to a relative maturity of these industries as well.

This work contributes to the mapping of the level of technological maturity of the industries of the State of Mato Grosso, also considering the size of these companies. Future research could analyze these indicators in different Brazilian states to obtain a comparison between different regions.

\section{REFERENCES}

${ }^{1}$ MUNIZ Jr., Jorge. Panorama Geral da Organização Industrial. Available at: https://www.youtube.com/watch?v=SBwg56ha8lk. Acessed on: 20 jun. 2020. 
${ }^{2} \mathrm{RAUCH}$, Erwin; LINDER, Christian; DALLASEGA, Patrick. Anthropocentric Perspective of Production before and within Industry 4.0. Computers \& Industrial Engineering, v. 139, 105644, jan. 2020.

${ }^{3}$ ZHONG, Ray Y.; XU, Xun; KLOTZ, Eberhard. Intelligent Manufacturing in the Context of Industry 4.0: A Review: Intelligent ManufacturingReview. Engineering, v. 3, n. 5, p. 616-630, oct. 2017.

4DAVIES, Robert; COOLE, Tim; SMITH, Alistair. Review of socio-technical considerations to ensure successful implementation of Industry 4.0. Procedia Manufacturing, v. 11, n. 1, p.1288-1295, jul. 2017.

${ }^{5}$ MUHURI, Pranab K.; SHUKLA, Amit K.; ABRAHAM, Ajith. Industry 4.0: A bibliometric analysis and detailed overview. Engineering Applications Of Artificial Intelligence, v. 78, p. 218-235, feb. 2019.

${ }^{6}$ SCHUH, Günter; ANDERL, Reiner; GAUSEMEIER, Jürgen; HOMPEL, Michael ten; WAHLSTER, Wolfgang (ed.). Industrie 4.0 Maturity Index: managing the digital transformation of companies. Munich: Acatech, 2017. 60 p. (ISSN 21926174). Disponível em: www.acatech.de/publikationen. Acessed on: 05 may 2020.

7 VELHO, Sérgio R. K.; SIMONETTI, Marcos L.; SOUZA, Carlos R. P.; IKEGAMI, Márcio Yoshiro. Nível de Maturidade Tecnológica: uma sistemática para ordenar tecnologias. Brasilia-DF. jul. 2017.

${ }^{8}$ SENAI 4.0. Avaliação de Maturidade: Indústria 4.0. 2019. Available at: https://senai40.com.br. Acessed on: 01 nov. 2019.

${ }^{9} \mathrm{CNI}$. Portal da Indústria. Available at: http://perfildaindustria.portaldaindustria.com.br/estado/mt. Acessed on: 22 jul. 2020.

${ }^{10}$ ANDERL, Reiner; PICARD, Andre; WANG, Yübo; FLEISCHER, Jürgen et al. Guideline Industrie 4.0 - Guiding principles for the implementation of Industrie 4.0 in small and medium sized businesses, VDMA Forum Industrie 4.0, Frankfurt, 2015, ISBN: 978-3-8163-0687-0. Available at https://www.researchgate.net/publication/312040745_Guideline_Industrie_40__Guiding_principles_for_the_implementation_of_Industrie_40_in_small_and_m edium_sized_businesses. Acesso em: 09 may 2020.

${ }^{11}$ SEBRAE. Anuário do Trabalho na Micro e Pequena Empresa. Available at: https://www.sebrae.com.br/Sebrae/Portal\%20Sebrae/Anexos/Anuario\%20do\%2 0Trabalho\%20Na\%20Micro\%20e\%20Pequena\%20Empresa 2013.pdf.

Acessed on: 22 jul 2020.

12NARCIZO, Ramon Baptista. UM MODELO DE REFERÊNCIA PARA A MATURIDADE DA CAPABILIDADE DE INOVAÇÃO EM MICRO E PEQUENAS EMPRESAS DE BAIXA TECNOLOGIA. 2017. 245 f. Tese 
(Doutorado) - Curso de Pós-Graduação e Pesquisa de Engenharia, Coppe, Universidade Federal do Rio de Janeiro, Rio de Janeiro, 2017.

${ }^{13}$ PORTER, Michael. Estratégia competitiva: técnicas para análise de indústrias e da concorrência. Rio de Janeiro: Campus, 2005. 448 p.

${ }^{14} \mathrm{HSM}$ (Brasil). Guia estratégico para a indústria $4.0 \mathrm{em}$ Tecnologia e Inovação. 2020. Disponível em: https://experience.hsm.com.br/posts/guiaestrategico-para-a-industria-

40\#: :text=Desenhar\%20uma\%20estrat\%C3\%A9gia\%20de\%20ind\%C3\%BAstr ia,alinhadas $\% 20$ com\%20a\%20estrat\%C3\%A9gia\%20global. Acesso em: 11 set. 2020. 